\title{
Downstream Copyright Infringers
}

\author{
Yvette Joy Liebesman *
}

\section{INTRODUCTION}

As a teenager, my vinyl record collection contained such classics as the Beach Boys' "Surfin' USA" and George Harrison's "My Sweet Lord." These and other songs were readily available at the Music Staff, a local record store that was one of the most popular hangouts of my youth. Even though both of these songs have been found to infringe the musical compositions of "Sweet Little Sixteen" respectively, my purchase and ownership of albums containing these songs never subjected me to copyright-infringement liability. Indeed, when the Chiffons sued George Harrison for copyright infringement in the 1970s for plagiarizing their musical composition of "He's So Fine,"3 neither party-nor anyone else-would have envisioned that the purchasers of Harrison's All Things Must Pass album, ${ }^{4}$ which included "My Sweet Lord," 5 would be considered infringers merely because they obtained a phonorecord ${ }^{6}$ of the sound recording, even though "My Sweet

\footnotetext{
* Assistant Professor of Law, Saint Louis University School of Law. I wish to thank Mark Lemley, Greg Vetter, Glynn S. Lunney, Jr., Raizel Liebler, Benjamin Wilson, Jennifer CarterJohnson, Julie Cromer Young, Matthew A. Levy, Chad Flanders, Marcia McCormick, and Peter Yu for their insightful comments, and my faculty fellow Renee Zerbonia for her excellent research assistance. In addition, I would like to thank fellow members of the BRR team, especially Helen Alexander Kratz, Brian Kratz, Heather Kelley, and Tomi Sampson for their unwavering support.

1. Chuck Berry Biography, THE ROCK AND ROLL HALl OF FAME AND Museum, http://rockhall.com/inductees/chuck-berry/bio/ (last visited Feb. 2, 2011) (discussing Chuck Berry's infringement suit against the Beach Boys).

2. Bright Tunes Music Corp. v. Harrisongs Music, Ltd., 420 F. Supp. 177, 181 (S.D.N.Y. 1976).

3. Id. at 178 .

4. George Harrison, All Things Must Pass (Capitol Records 1970).

5. Id.

6. Under the Copyright Act of 1976, sound recordings are fixed in "phonorecords"; other works are fixed as “copies.” 17 U.S.C. § 101 (2006). “"Phonorecords' are material objects in which sounds ... are fixed by any method ... and from which the sounds can be perceived, reproduced, or otherwise communicated, either directly or with the aid of a machine or device.... [This definition] includes the material object in which the sounds are first fixed." Id. "The term 'copies' includes the material object, other than a phonorecord, in which the work is first fixed." Id.; see also LondonSire Records, Inc. v. Doe 1, 542 F. Supp. 2d 153, 165 n.14 (D. Mass. 2008) (“The two terms [copy
} 
Lord" was an unauthorized copy and adaptation of the Chiffons' musical composition. The mere act of purchasing a material copy or a phonorecord ${ }^{7}$ does not infringe any of a copyright owner's enumerated rights under either the Copyright Act of $1909^{8}$ or the Copyright Act of 1976 (the 1976 Act). ${ }^{9}$

The advent and rapid growth of online music retailers has provided musicians new avenues to sell their songs. Artists can digitally save their sound recordings as MP3 files. ${ }^{10}$ An artist may release these files through online stores like iTunes, where consumers may access, pay for, and make an authorized copy of a song. ${ }^{11}$ One expected result of online legal music downloading has been its effect on brick-and-mortar record stores and CD manufacturers. In the last five years, many music retailers have closed, including Tower Records, ${ }^{12}$ Sam Goody, ${ }^{13}$ and a multitude

and phonorecord] appear to be functionally interchangeable ... differing only in the nature of the copyrighted work.”) (citing H.R. REP. 94-1476, at 53 (1976), reprinted in 1976 U.S.C.C.A.N. 5659, 5666).

7. This would also apply to purchases of the musical composition in the form of sheet music or fixed as a copy in any other form. See 17 U.S.C. § 101.

8. The district court decided Harrisongs in 1976, prior to the January 1, 1978 effective date of the Copyright Act of 1976. 420 F. Supp. at 177; see also Copyright Act of 1976, Pub. L. No. 94553, § 102, 90 Stat. 2541, 2598-99 (1976) (noting effective date of Jan. 1, 1978) (codified as amended at 17 U.S.C. §§ 101-810 (2006)). Under the Copyright Act of 1909, copyright owners had the exclusive rights to "print, reprint, publish, copy, and vend" the work; to translate the work into other languages or dialects; to publicly perform or display the work; and to produce and distribute the work. Copyright Act of 1909, Pub. L. No. 60-349, § 1, 35 Stat. 1075, 1075 superseded by 17 U.S.C. §§ 101-810 (2006). A consumer purchasing, receiving, or possessing a copy of a copyrighted work does not infringe any of these rights.

9. The six enumerated rights of copyright owners under the Copyright Act of 1976 are the reproduction right, the adaptation right, the distribution right, the public-display and publicperformance rights, and, for sound recordings, the digital-broadcast right. 17 U.S.C. § 106. Purchasing a phonorecord — the physical embodiment of a sound recording — does not fall into any of these categories.

10. MP3 is one of the dominant audio files types used in downloading. Musical sounds can be turned into a digital form and recorded onto a compact disc (CD). But in the format on CDs, three minutes of a sound recording translates to a 30 megabyte file, or 30 million bytes of data, which may be too large for downloading. What Are MP3 Files and How Do They Work?, How STUFF WORKS, http://electronics.howstuffworks.com/question118.htm (last visited Aug. 22, 2011). To compress that large song file into a smaller format that is more quickly downloaded, the Moving Picture Experts Group (MPEG) developed a compression system for sound recordings called MPEG Audio Layer-3, or MP3, which "can compress a song by a factor of 10 or 12 and still retain something close to CD quality." Id. Therefore, that 30-megabyte sound file from a CD reduces to about 3 megabytes in MP3 format. Id.

11. See, e.g., iTunes, APPLE, http://www.apple.com/itunes/ (last visited Jan. 23, 2011).

12. The Day Music Died? No, but Tower Records Is, MsnBc.com (Oct. 15, 2006, 9:43 PM), http://www.msnbc.msn.com/id/15251144/ns/business-us_business/.

13. Greg Sandoval, More Consolidation Among Major Music Labels? CNET News (Jan. 20, 2011, 6:54 PM), http://news.cnet.com/8301-31001_3-20029136-261.html. 
of smaller music proprietorships. ${ }^{14}$ Sony has shut down and consolidated CD manufacturing facilities. ${ }^{15}$ In 2009, downloaded music accounted for $98 \%$ of all individual songs sold, and $12 \%$ of all albums sold. ${ }^{16}$

Recent scholarship has addressed digital-music issues such as peerto-peer unauthorized downloading of songs, ${ }^{17}$ the future of online music distribution, ${ }^{18}$ tactics used by the entertainment industry to curtail unauthorized copying, ${ }^{19}$ and the social acceptability of music sampling. ${ }^{20}$ Still, there is a lurking issue yet to be addressed: one unintended

14. Justin Pope, Record Stores Closing in U.S. at Record Rates, DESERET NEWS (Mar. 30, 2008, 12:08 AM), http://www.deseretnews.com/article/695265521/Record-stores-closing-in-US-atrecord-rates.html.

15. William Fenton, Report: Sony Shutting Down CD Manufacturing Plant in N.J., PCMAG.COM (Jan. 13, 2011, 11:23 AM), http://www.pcmag.com/article2/0,2817,2375682,00.asp.

16. Lexton Snol, Single Track Downloads Dominate, PCWorLD (Jan. 30, 2011, 10:04 AM), http://www.pcworld.com/article/218172/single_track_downloads_dominate.html. The overall number of albums sold in any form, CD or digital, has declined 7\% between 2007 and 2009, whilethanks to the ability to download individual songs rather than purchase an entire album - the number of singles sold has grown 76\%. Id.; see also Caitlin Kenney, Album Sales Hit Record Lows. Again., NPR (Aug. 26, 2010 1:29 PM), http://www.npr.org/blogs/money/2010/08/25/129428450/albumsales-hit-record-lows.

17. See, e.g., Mark A. Lemley \& R. Anthony Reese, A Quick and Inexpensive System for Resolving Peer-to-Peer Copyright Disputes, 23 CARDOzO ARTS \& ENT. L.J. 1 (2005) (discussing peer-to-peer file sharing and related copyright issues); Chad A. Sanders, Note, Maverick Recording Co. v. Whitney Harper: How the Fifth Circuit Virtually Eliminated Innocent Infringers Without Noticing, 13 TUL. J. TECH. \& INTELL. PROP. 295 (2010) (analyzing case dealing with peer-to-peer file sharing and copyright infringement).

18. See, e.g., Robert J. Delchin, Music Copyright Law: Past, Present and Future of Online Music Distribution, 22 CARDOZO ARTS \& ENT. L.J. 343 (2004) (discussing legal developments in online music distribution).

19. See, e.g., Peter K. Yu, The Graduated Response, 62 FlA. L. REV. 1373 (2010) (discussing entertainment industry tactics to address online copyright infringement); Jordana Boag, Comment, The Battle of Piracy versus Privacy: How the Recording Industry Association of America (RIAA) Is Using the Digital Millennium Copyright Act (DMCA) As Its Weapon Against Internet Users' Privacy Rights, 41 CAL. W. L. REV. 241 (2004) (discussing RIAA counter-piracy efforts); Kate Cross, Comment, David v. Goliath: How the Record Industry Is Winning Substantial Judgments Against Individuals for Illegally Downloading Music, 42 TEX. TECH L. REV. 1031 (2010) (analyzing damages in suits brought by the RIAA).

20. See, e.g., Kembrew McLeod \& Peter DiCola, Creative LiCense: The LAW And CUlture OF DigITAL SAMPLING (2011) (discussing the history, licensing, and future of music sampling); Mark A. Edwards, Acceptable Deviance and Property Rights, 43 ConN. L. REV. 457 (2010) (discussing divergences between social acceptability and legality of behavior with regard to property rights); Michael J. Madison, Intellectual Property and Americana, or Why IP Gets the Blues, 18 FORDHAM INTELL. PROP. MEDIA \& ENT. L.J. 677, 702-03 (2008) (noting effect of intellectual property law on "the arc of . . blues [music] and its descendants"); David Mongillo, The Girl Talk Dilemma: Can Copyright Law Accommodate New Forms of Sample-Based Music?, 9 PITT. J. TECH. L. \& POL'Y 1 (2009) (discussing copyright-infringement issues related to audio sampling); Jeffrey Omari, Mix and Mash: The Digital Sampling of Music Has Stretched the Meaning of the Fair Use Defense, L.A. LAw., Sept. 2010, at 35 (discussing recent developments in music sampling disputes). 
consequence of the ability to sell songs through downloads is a new, and yet unnoticed, way to infringe copyrights, which, unless remedied, could lead to new classes of defendants never contemplated in the 1976 Act's protections for artists, musicians, and authors.

Unlike a brick-and-mortar transaction, the act of purchasing a song on the web requires that the purchaser "download" a digital file of the song - that is, make a copy of the song that is located on the vendor's website and transfer that copy to the consumer's computer. Thus, downloading copies and phonorecords triggers copyright protections every time a consumer purchases and downloads a song from an online music retailer. ${ }^{21}$ The consumer benefits at the expense of one of the rights of the copyright owner-the reproduction right. ${ }^{22}$ Of course, by making one's song available for download, the copyright owner allows for such a reproduction.

But suppose the downloaded song is later the subject of an infringement suit regarding the melody or lyrics in the underlying musical composition. ${ }^{23}$ Every time the alleged infringer's musical composition - which is fixed in the digital file of the sound recording-is downloaded, the purchaser of the downloaded file has made an unauthorized reproduction of an unauthorized adaptation of the plaintiff's musical work. To borrow from the Harrisongs example, George Harrison's "My Sweet Lord" constituted an unauthorized adaptation of the Chiffons' "He's So Fine."24 Thus, a consumer's download of "My Sweet Lord" would be an unauthorized reproduction of an unauthorized adaptation of "He's So Fine."

While the Chiffons and Harrison resolved their litigation decades ago-leaving purchasers of "My Sweet Lord" safe from liability—rapper Biz Markie faced an infringement suit in the $1990 \mathrm{~s}^{25}$ and rapper 50 Cent was recently sued for allegedly taking another artist's instrumental. ${ }^{26}$

21. Because downloading music, videos, or movies from a peer-to-peer network creates an unauthorized reproduction of a copyrighted work, the downloading party may incur copyrightinfringement liability. See generally A\&M Records, Inc. v. Napster, Inc., 239 F.3d 1004 (9th Cir. 2001) (detailing logistics of peer-to-peer file sharing).

22. See 17 U.S.C. § 106(1) (2006).

23. See Acuff-Rose Music, Inc. v. Jostens, Inc., 988 F. Supp. 289, 292 (S.D.N.Y. 1997) (“A copier will be liable for copying the musical work in its entirety, that is, the composition's words and music together, as well as for copying just the music or the words alone.” (citing PAUL GOLDSTEIN, COPYRIGHT § 2.8 (2d ed. 1996))).

24. See supra notes $2-5$ and accompanying text.

25. See Grand Upright Music Ltd. v. Warner Bros. Records, Inc., 780 F. Supp. 182 (S.D.N.Y. 1991)

26. Rich Jones, 50 Cent Sued for Copyright Infringement Over "I Get Money", AssociATED 
This may expose online purchasers of both rappers' works to infringement liability. ${ }^{27}$

In 1991, Biz Markie was found to have infringed Gilbert O’Sullivan's musical composition, “Alone Again (Naturally).,"28 Markie admitted to sampling a portion of O'Sullivan's work for use in his song "Alone Again."29 O'Sullivan ultimately enjoined Markie's use of the sampling. ${ }^{30}$ The district court rejected the defendants' argument that the pervasiveness of music sampling in the rap industry should excuse the infringement. ${ }^{31}$

In the case of 50 Cent, ${ }^{32}$ his song "I Get Money" is currently the subject of dispute in litigation with Caliber, another rap artist. ${ }^{33}$ Caliber claims that the instrumental in 50 Cent's song infringes Caliber's copyright ownership of the track. ${ }^{34}$ "I Get Money" went double platinum, ${ }^{35}$ selling over two million copies as either a single or as a track on the album Curtis. ${ }^{36}$ Even if only half of those purchases were downloads, that translates to one million consumers infringing Caliber's reproduction right. The combined statutory damages that Caliber could

CONTENT FROM YAHOO! (Jan. 3, 2011), http://www.associatedcontent.com/article/6162288/50_ cent_sued_for_copyright_infringement.html?cat=33.

27. See infra Part III for a detailed discussion.

28. Grand Upright Music, 780 F. Supp. at 185.

29. Id. at 183 ("Defendants admit "that the Biz Markie album "I Need A Haircut" embodies the rap recording “Alone Again” which uses three words from "Alone Again (Naturally)” composed by Gilbert O'Sullivan and a portion of the music taken from the O'Sullivan recording.'”). For an explanation of sampling see Bridgeport Music, Inc. v. Diamond Time, Ltd., 371 F.3d 883, 886 (6th Cir. 2004) (explaining that "[s]ampling, common in rap, hip-hop, and urban music, typically involves making a digital copy from a master sound recording and using a piece in the making of a new work"). For a detailed discussion of the legal issues involved in sampling, see Carlos Ruiz de la Torre, Digital Music Sampling and Copyright Law: Can the Interests of Copyright Owners and Sampling Artists Be Recorded?, 7 VAND. J. ENT. \& TECH. L. 401 (2005); Stephen R. Wilson, Music Sampling Lawsuits: Does Looping Music Samples Defeat the De Minimis Defense?, 1 J. HIGH TECH. L. 179 (2002).

30. Grand Upright Music, 780 F. Supp. at 185.

31. Id. at 183 ("[T] he defendants in this action ... would have this court believe that stealing is rampant in the music business and, for that reason, their conduct here should be excused. The conduct of the defendants herein, however, violates not only the Seventh Commandment, but also the copyright laws of this country.”).

32. 50 Cent is the performing name of Curtis James Jackson III. 50 Cent, WIKIPEDIA, http://en.wikipedia.org/wiki/50_Cent (last visited Feb. 5, 2011).

33. Jones, supra note 26.

34. Id.

35. I Get Money, WIKIPEDIA, http://en.wikipedia.org/wiki/I_Get_Money (last visited Feb. 1, 2011).

36. See Certification Criteria, RECORDING INDUSTRY ASS'N OF AM., http://www.riaa.com/ goldandplatinum.php?content_selector=criteria (last visited Feb. 1, 2011). 
collect would range between $\$ 750$ million and $\$ 30$ billion. $^{37}$ It may only be a matter of time before the copyright holders of musical compositions sue consumers over downloads of songs that are the subject of infringement suits.

Through the Internet, copyright infringement has taken on new dimensions never foreseen by the legislators who enacted the 1976 Act. In an effort to address this overlooked area of potential liability, this Article urges legislative action. Rather than waiting for the courts to find a downstream defendant liable under such circumstances, ${ }^{38}$ Congress should shield innocent consumers from liability for statutory damages for purchasing copies of songs they thought they were legally allowed to own.

This Article approaches this dilemma by first describing the state of "traditional" copyright infringement in the brick-and-mortar world in Part II. Part III details how copyright infringement on the Internet diverges from the traditional mode based on the difference in how the work is fixed and purchased. It also illustrates how downstream infringement by the consumer occurs through the downloading of an infringing song from a legitimate music retailer - an act that is several steps removed from the original infringement by the defendantmusician. ${ }^{39}$ This section then discusses the effects of these internet

37. See 17 U.S.C. $\S 504(c)(1)$. The Statutory Damages provision of the 1976 Act states that: [T] he copyright owner may elect . . . to recover, instead of actual damages and profits, an award of statutory damages for all infringements involved in the action, with respect to any one work, for which any one infringer is liable individually . . . in a sum of not less than $\$ 750$ or more than $\$ 30,000$ as the court considers just.

Id. Engaging in some simple math shows that if one million music lovers downloaded an infringing song, such as "I Get Money," then the plaintiff-in this instance, Caliber-could receive anywhere between $\$ 750$ million and $\$ 30$ billion if he was able to collect from every person who infringed. There is, however, some relief for the "innocent" infringer:

In a case where the infringer sustains the burden of proving, and the court finds, that such infringer was not aware and had no reason to believe that his or her acts constituted an infringement of copyright, the court in its discretion may reduce the award of statutory damages to a sum of not less than $\$ 200$.

Id. $\S 504(\mathrm{c})(2)$. If every consumer defended herself in court and met this burden, Caliber would collect a minimum of $\$ 200$ million. See infra Parts III and IV for further discussion on innocent infringers and a proposed modification of this section of the statute.

38. Alternatively, courts could find that consumers are not subject to liability-even though copyright infringement is a tort of strict liability-under the 1976 Act. See infra Part III.

39. If one considers the original act of infringement to be the creation of the unauthorized derivative work by the defendant composer or musician, then the sound recording of that infringing work would be one step removed; distributing the sound recording to online music retailers would be two steps removed from the original infringing activity. The distribution by the online retailer would be three steps away, and, finally, the purchase and download by the consumer would be four steps 
purchases on a class of third-party infringers: those musician-defendants who create infringing works and provide sound recordings for download. Part IV addresses public policy that supports reducing the liability of downstream copyright infringers and foretells some ramifications of allowing these suits to proceed. Part V then proposes solutions to shield consumers from downstream-infringement liability. This Article concludes with final thoughts on the necessity of ensuring that consumers are not caught in the legitimate web of composers protecting their musical compositions, and how allowing infringement actions against unforeseen downstream defendants can affect overall fidelity to the rule of law.

\section{BUYING THAT INFRINGING CD AT THE SWAP MEET}

In order to frame the discussion on why consumers who are downstream from the infringing activity should not be held liable for the actions of upstream infringing musicians, some historical context proves useful. Prior to the advent of music downloading from the Internet, one could only obtain an authorized phonorecord of a sound recording by visiting a brick-and-mortar store or other retailer ${ }^{40}$ and purchasing the material object-such as a vinyl record, cassette, eight-track tape, or CD-in which the sound recording was "fixed." Through this world view, Congress enacted the Copyright Act of 1976. This section, therefore, first explores the liabilities faced by a consumer who legally purchases a material object that embodies an infringing musical composition.

\section{A. Civil Liability Under the Copyright Act}

Going to a store and purchasing a CD containing either an authorized or unauthorized phonorecord does not involve any of the enumerated rights under $\S 106$ of the Copyright Act. ${ }^{41}$ The consumer has not copied the musical composition or sound recording and fixed that copy in a tangible medium of expression. She has not distributed a material object containing the copyrighted work, and she has not made an adaptation of

downstream from the original infringing act.

40. As a young woman, I also frequently purchased music at "swap meets," flea markets, and garage sales. While some of these venues probably sold pirated music, most also sold a large quantity of new and used authorized phonorecords.

41. See 17 U.S.C. § 106 (2006). 
or publicly broadcast the songs contained on the CD. Even if the seller of the CD infringes one of these rights, the purchaser does not. Thus, in the brick-and-mortar world, consumers do not infringe a copyright owner's rights when they purchase a material object, even if it embodies an unauthorized copy or phonorecord. ${ }^{42}$

A brick-and-mortar sale of the infringing 50 Cent CD infringes the distribution rights of Caliber and subjects the retailer to strict liability. ${ }^{43}$ And the musician who wrote and recorded the infringing song may also incur liability for (1) vicarious or (2) contributory infringement based on the actions of the retailer.

To prove vicarious liability, a plaintiff must show that the defendant "has the right and ability to supervise the infringing activity and also has a direct financial interest in such activities." 44 No knowledge of the infringing activity is required. ${ }^{45}$ The musician who has recorded an infringing song and distributes it-either directly or through a record label - has both actual control over the sale of those phonorecords and a definite financial interest in their sale.

To be held liable for contributory infringement, two elements must be proven: (1) that a defendant has "knowledge of the infringing activity"; and (2) that the defendant "induces, causes or materially contributes to the infringing conduct of another." ${ }^{46}$ Again, in addition to facing direct liability, the musician who wrote and recorded the

42. See id. § 501(a) (“Anyone who violates any of the exclusive rights of the copyright owner as provided by sections 106 through $122 \ldots$ is an infringer of the copyright or right of the author, as the case may be.”), invalidated in part by Nat. Ass'n of Bds. of Pharmacy v. Bd. of Regents, 633 F.3d 1297 (11th Cir. 2011) (declaring § 501(a) unconstitutional to the extent it conflicts with state sovereign immunity).

43. See id. § 106(3) (giving the owner of a copyright the exclusive right to authorize distribution of copies or phonorecords of the copyrighted work to the public by sale). Suits of this nature are not unprecedented; in the 1980s, several small music retail stores were sued for distributing unauthorized copies of CDs. See generally Stan Soocher, He's The No. 1 Bane of Pirates: CD Copies Worry the Music Business, NAT'L L.J., June 19, 1989, at 2.

44. Gershwin Publ'g Corp. v. Columbia Artists Mgmt., Inc., 443 F.2d 1159, 1162 (2d Cir. 1971) (citing Shapiro, Bernstein \& Co., Inc. v. H. L. Green Co., 316 F.2d 304 (2d Cir. 1963); Case Note, Television Sponsor and Advertising Agency Held Vicariously Liable for Copyright Infringement-Davis v. E. I. DuPont de Nemours \& Co., 64 MiCH. L. REv. 1172, 1175-78 (1966)); see also Fonovisa, Inc. v. Cherry Auction, Inc., 76 F.3d 259, 262 (9th Cir. 1996).

45. Shapiro, Bernstein \& Co., 316 F.2d at 307 ("When the right and ability to supervise coalesce with an obvious and direct financial interest in the exploitation of copyrighted materialseven in the absence of actual knowledge that the copyright monopoly is being impaired-the purposes of copyright law may be best effectuated by the imposition of liability upon the beneficiary of that exploitation." (citation omitted) (citing De Acosta v. Brown, 146 F.2d 408 (2d Cir. 1944))).

46. Gershwin Publ'g, 443 F.2d at 1162 (footnote omitted) (citing Fortnightly Corp. v. United Artists Television, Inc., 392 U.S. 390 (1968)). 
infringing song could incur third-party liability on the theory of contributory infringement. The infringer-musician has knowledge of the music store's distribution of the infringing phonorecord and materially contributes by providing the phonorecord for sale in the record store.

The infringing musician may also face a claim of inducing copyright infringement; however, "the standard for inducement liability is providing a service 'with the object of promoting its use to infringe copyright.' '[M]ere knowledge of infringing potential or actual infringing uses would not be enough here to subject [a defendant] to liability.",47 A musician's liability for inducing the record store to infringe on the copyright owner's distribution right will depend on proving that the musician took " "active steps... to encourage direct infringement,' such as advertising an infringing use or instructing how to engage in an infringing use." 48 This may be difficult to prove-the musician's goals are to create music and make money, not to induce record stores to infringe. ${ }^{49}$

\section{B. Criminal Liability}

Currently, federal prosecutors target primarily manufacturers, distributors, and transporters ${ }^{50}$ of bootlegged ${ }^{51}$ and pirated $^{52}$ goods. Prosecutors have attempted to use the National Stolen Property Act, ${ }^{53}$

47. Perfect 10, Inc. v. Visa Int'l Serv., Ass’n, 494 F.3d 788, 801 (9th Cir. 2007) (alterations in original) (citation omitted) (quoting Metro-Goldwyn-Mayer Studios Inc. v. Grokster, Ltd., 545 U.S. 913, 936-37 (2005)).

48. Grokster, 545 U.S. at 936 (citation omitted) (quoting Oak Indus., Inc. v. Zenith Elecs. Corp., 697 F. Supp. 988, 992 (N.D. Ill. 1988)). “[A] showing that infringement was encouraged overcomes the law's reluctance to find liability when a defendant merely sells a commercial product suitable for some lawful use.” Id.

49. For a finding of inducement, there would have to be "evidence of express promotion, marketing, and intent to promote further, [and] the business models employed by" the musician would have to show that her principal object for providing the sound recordings to record stores was for the purposes of infringing on the plaintiff's musical work. Id. at 926.

50. 17 U.S.C. § 506(a) (2006).

51. According to the Supreme Court, “[a] 'bootleg' phonorecord is one which contains an unauthorized copy of a commercially unreleased performance.” Dowling v. United States, 473 U.S. 207, 209 n.2 (1985).

52. A “pirated" phonorecord refers to "an unauthorized copy of a performance already commercially released," id., "but with new packaging.” Soocher, supra note 43, at 2. A "counterfeit" is a "duplication of not only previously released sound recordings, but [of] also the original packaging." Id. at 2. As noted by the Court in Dowling, the terms "bootleg” and "pirated" are often used interchangeably. 473 U.S. at 209 n.2.

53. Dowling, 473 U.S. at 208. 
which criminalizes the interstate transportation of stolen property, to target transporters of bootlegged, pirated, and counterfeit goods. ${ }^{54}$ The Supreme Court, however, held that the transportation of bootleg phonorecords did not fall within the reach of $\S 2314$ 's definition of "stolen goods." 55

Justice Blackmun, writing for the majority, declared that "interference with copyright does not ... equate with theft, conversion, or fraud. The [1976 Act] even employs a separate term of art to define one who misappropriates a copyright." 56 The Court elaborated on the difference between theft or conversion of a physical object and infringement of a copyright:

The infringer invades a statutorily defined province guaranteed to the copyright holder alone. But he does not assume physical control over the copyright; nor does he wholly deprive its owner of its use. While one may colloquially liken infringement with some general notion of wrongful appropriation, infringement plainly implicates a more complex set of property interests than does run-of-the-mill theft, conversion, or fraud. ${ }^{57}$

Today, a transporter of bootleg phonorecords could face prosecution under the Piracy and Counterfeiting Amendments Act of 1982. ${ }^{58}$ There is, however, no criminal liability for the purchasers of unauthorized copies or phonorecords. Section 506(a) provides that:

Any person who willfully infringes a copyright shall be punished as provided under section 2319 of title 18, if the infringement was committed-

54. 18 U.S.C. § 2314 (2006). For further discussion regarding the growth of unauthorized sound recordings, see David Schwartz, Note, Strange Fixation: Bootleg Sound Recordings Enjoy the Benefits of Improving Technology, 47 FED. COMM. L.J. 611 (1995).

55. Dowling, 473 U.S. at 216.

56. Id. at 217.

57. Id. at 217-18. State courts have also found that statutes criminalizing the possession of stolen property do not encompass the possession of materials that contain infringing works. See, e.g., People v. Borriello, 587 N.Y.S.2d 518, 522 (N.Y. Sup. Ct 1992) (noting that under the alternative view "a person who purchases a duplicate of a 'Gucci' or 'Dior' or some other designer item, which the person has reason to believe is unauthorized, would commit the crime of possessing stolen property").

58. Pub. L. No 97-180, 96 Stat. 91, 93 (codified as amended at 17 U.S.C. § 506(a) (2006)). The Supreme Court noted that the government conceded this point in its opposition of Dowling's petition for a writ of certiorari by "acknowledg[ing] that it no longer need[ed] § 2314 to prosecute and punish serious copyright infringement" and could instead rely on this new statute. Dowling, 473 U.S. at 228 n.21. 
(A) for the purposes of commercial advantage or private financial gain;

(B) by the reproduction or distribution ... of 1 or more copies or phonorecords of 1 or more copyrighted works, which have a total retail value of more than $\$ 1,000$; or

(C) by the distribution of a work being prepared for commercial distribution, by making it available on a computer network accessible to members of the public, if such person knew or should have known that the work was intended for commercial distribution. ${ }^{59}$

Other provisions in the federal criminal code similarly punish traffickers and those who make unauthorized fixations or distributions, but not those who receive the goods. ${ }^{60}$

\section{MUSIC IN THE INTERNET ERA}

The 1998 launch of the website Ritmoteca.com revolutionized the acquisition of sound recordings by consumers. ${ }^{61}$ No longer were consumers limited to the selection at the local record shop; the universe of available genres became almost infinite. Online music stores have made it easier for consumers to purchase music from both well-known and obscure artists; new and unknown bands now have the ability to find an audience for their music.

In a brick-and-mortar transaction, a consumer does not make a copy when she buys a song; rather, she purchases a material object which embodies a phonorecord of the copyrighted work. Internet stores such as

59. 17 U.S.C. § 506(a) (emphasis added).

60. See 18 U.S.C. § 2319 (2006) (providing criminal sanctions for violations of 17 U.S.C. § 506); id. § 2319A (criminalizing the unauthorized fixation, transmission, and distribution of sound recordings and music videos of live musical performances); id. § 2319B (criminalizing the "[u]nauthorized recording of Motion pictures in a Motion picture exhibition facility" (emphasis added)); id. § 2320 (criminalizing “[t] rafficking in counterfeit goods or services” (emphasis added)). For the most part, states are preempted from enacting similar laws. See, e.g., People v. Williams, 920 N.E.2d 446, 457 (Ill. 2009) (holding that the Illinois criminal statute regarding piracy of sound recordings was preempted by the Federal Copyright Act). Several states have managed to enact similar statutes that have survived preemption challenges. See, e.g., People v. Anderson, 286 Cal. Rptr. 734, 739 (Cal. Ct. App. 1991) (holding that a statute criminalizing the advertising, offering, or possessing for sale of pirated recordings or audiovisual works is not preempted by federal law). But none of these address the unknowing purchase or possession of unauthorized copies or phonorecords. See, e.g., Cal. Penal Code § 653w (West 2010); GA. Code AnN. § 16-8-60 (West 2003); N.J. STAT. ANN. § 2C:21-21 (West 2005).

61. Ritmoteca.com is credited with being one of the first online music stores. Online Music Store, WIKIPEDIA, http://en.wikipedia.org/wiki/Online_music_store (last visited Feb. 1, 2011). 
iTunes, CD Universe, and Amazon.com work differently-they sell songs via downloads. "A download is a transmission of an electronic file containing a digital copy of a musical work ${ }^{62}$ that is sent from an on-line server to a local hard drive." 63 Under the Copyright Act, this downloaded electronic file is considered a material object. ${ }^{64}$ "The Copyright Act ... does not use materiality in its most obvious sense- to mean a tangible object with a certain heft, like a book or compact disc. Rather, it refers to materiality as a medium in which a copyrighted work can be 'fixed." ",65

Thus, any object in which a sound recording can be fixed is a "material object." That includes ... electronic files .... . [For example, w]hen a user on a peer-to-peer network downloads a song from another user, he receives into his computer a digital sequence representing the sound recording. That sequence is magnetically encoded on a segment of his hard disk (or likewise written on other media.) With the right hardware and software, the downloader can use the magnetic sequence to reproduce the sound recording. The electronic file (or, perhaps more accurately, the appropriate segment of the hard disk) is therefore a "phonorecord" within the meaning of the [1976 Act]. ${ }^{66}$

Thus, "the delivery of a music file to a purchaser via a download constitutes a mechanical reproduction of the copyrighted work in the

62. Under the 1976 Act, musical works are copyrightable subject matter. 17 U.S.C. § 102(a)(2); see also Acuff-Rose Music, Inc. v. Jostens, Inc., 988 F. Supp. 289, 292 (S.D.N.Y. 1997) ("It is well-established that 'musical works, including any accompanying words,' may be copyrighted under 17 U.S.C. § 102(a)(2).”).

63. United States v. Am. Soc'y of Composers, Authors \& Publishers, 627 F.3d 64, 69 (2d Cir. 2010) (citing United States v. Am. Soc'y of Composers, Authors \& Publishers, 485 F. Supp. 2d 438, 411 (S.D.N.Y. 2007)).

64. See London-Sire Records, Inc. v. Doe 1, 542 F. Supp. 2d 153, 170-71 (D. Mass. 2008) (citing 17 U.S.C. § 101).

65. Id. at 171 (citing 17 U.S.C. § 101). The Copyright Act provides that "“[a] work is "fixed” in a tangible medium of expression when its embodiment in a copy or phonorecord,... is sufficiently permanent or stable to permit it to be perceived, reproduced, or otherwise communicated for a period of more than transitory duration.” 17 U.S.C. § 101 . "The sole purpose of the term 'material object' is to provide a reference point for the terms 'phonorecords' and 'fixed."' LondonSire Records, 542 F. Supp. 2d at 171.

66. Id. (citing 17 U.S.C. § 101); accord Matthew Bender \& Co. v. West Publ'g Co., 158 F.3d 693, 703-04 (2d Cir. 1998); Stenograph L.L.C. v. Bossard Assocs., Inc., 144 F.3d 96, 100 (D.C. Cir. 1998); Working Grp. ON Intellectual Prop. Rights, Intellectual Property and the NATIONAL INFORMATION INFRASTRUCTURE 213 (1995), available at http://www.uspto.gov/go/com/ doc/ipnii/ipnii.pdf (noting that electronic transmissions implicate copyright holders' rights and strongly implying that electronic files constitute "material objects"). 
form of a 'digital phonorecord delivery' as set forth in 17 U.S.C. § 115(d)."67

Purchasing a song online requires an authorized copying of that song from the music store's website or server onto the customer's computer. ${ }^{68}$ A consumer could reasonably assume that the songs on the legitimate online music store available for purchase are there with the permission of the copyright owners and that any copying done in conjunction with the transaction is an authorized reproduction-that is, upon payment, the consumer has the permission of the copyright owner to create and download a copy. ${ }^{69}$

\section{A. Consumers as Downstream Infringers}

Suppose, however, the purchased song is infringing on another musical composition. Since copyright infringement is a tort of strict liability, "a plaintiff need not prove wrongful intent or culpability in order to prevail.... Even an innocent copier-for example, one who copies in the belief that the infringed work is in the public domain or without realizing that he or she is copying-is liable ....70 It does not

67. Am. Soc'y of Composers, Authors \& Publishers, 485 F. Supp. 2d at 447; see also 17 U.S.C. $\S 115(\mathrm{c})(3)(\mathrm{G})(\mathrm{i})$ ("A digital phonorecord delivery of a sound recording is actionable as an act of infringement . . . unless (I) the digital phonorecord delivery has been authorized by the copyright owner of the sound recording, and (II) . . . has otherwise been authorized by the copyright owner of the musical work to distribute or authorize the distribution, by means of a digital phonorecord delivery, of each musical work embodied in the sound recording.").

68. See Stenograph, 144 F.3d at 100 ("The language of the Copyright Act, case law, and common sense support the proposition that the installation of software onto a computer results in 'copying' within the meaning of the [1976 Act].” (citing 17 U.S.C. § 101; 2 MELVILLE B. NiMMER \& DAVID NIMMER, NIMMER ON COPYRIGHT § 8.08[A][1], at 8-113 (1997))); Vault Corp. v. Quaid Software Ltd., 847 F.2d 255, 260 (5th Cir. 1988) (“[T]he act of loading a program from a medium of storage into a computer's memory creates a copy of the program.”).

69. Even without express permission, the downloading could be interpreted to be a § 117(a)(1) exception. See 17 U.S.C. § 117(a)(1) ("Notwithstanding the provisions of section 106, it is not an infringement for the owner of a copy of a computer program to make or authorize the making of another copy or adaptation of that computer program provided that such a new copy or adaptation is created as an essential step in the utilization of the computer program in conjunction with a machine and that it is used in no other manner.").

70. Faulkner v. Nat'l Geographic Soc’y, 576 F. Supp. 2d 609, 613 (S.D.N.Y. 2008). Intent does, however, play a role in determining remedies:

[L]ack of culpability may bear on statutory damages where those are in issue.... In consequence, there is no proper role for proof of wilfulness [regarding liability]. Its only function would be in service of an attempt by plaintiff to prejudice the jury's assessment of damages and, if it proves to be in issue, liability by portraying defendants in an unflattering light.

Id. (footnote omitted). 
matter even if the "innocent" copier had obtained an explicit warrant that use of the material would not infringe anyone's rights. ${ }^{71}$ Thus, under this strict liability standard, even these "innocent" downstream infringersthat is, those who are unaware that they are downloading an unauthorized copy of a song - are liable for infringement. One might think that the Recording Industry Association of America (RIAA) would not pursue these claims. They are not, however, above suing twelve-year-old girls ${ }^{72}$ or the deceased. ${ }^{73}$

For "innocent" infringers who can prove a good-faith belief that they were not infringing, there is a reduction in statutory damages:

In a case where the infringer sustains the burden of proving, and the court finds, that such infringer was not aware and had no reason to believe that his or her acts constituted an infringement of copyright, the court in its discretion may reduce the award of statutory damages to a sum of not less than $\$ 200 .^{74}$

This relief, however, was not designed to limit the damages to downstream consumer infringers-rather, it was designed to help publishers and broadcasters who printed, distributed, or publicly performed a work under the mistaken assumption that they had permission to do so. ${ }^{75}$ The legislative history shows that Congress recognized infringement liability's potential to stifle the public's access to creative works. ${ }^{76}$ Thus, Congress sought to encourage publishers and

71. See Bryant v. Europadisk, Ltd., No. 07 Civ 3050(WGY), 2009 WL 1059777, at *5-6 (S.D.N.Y. Apr. 15, 2009); see also De Acosta v. Brown, 146 F.2d 408, 411 (2d Cir. 1944).

72. 12-Year-Old Settles Music Swap Lawsuit, CNN (Feb. 18, 2004), http://articles.cnn.com/ 2003-09-09/tech/music.swap.settlement_1_riaa-cary-sherman-kazaa?_s=PM:TECH.

73. Andrew Orlowski, RIAA Sues the Dead, REgISTER (Feb. 5, 2005, 2:30 AM) http://www.theregister.co.uk/2005/02/05/riaa_sues_the_dead/.

74. 17 U.S.C. $\S 504(c)(2)$.

75. S. REP. No. 94-473, at 145 (1975).

The "innocent infringer" provision of section 504(c)(2) has been the subject of extensive discussion. The exception, which would allow reduction of minimum statutory damages to $\$ 100$ [, which has since been raised to $\$ 200$,] where the infringer "was not aware and had no reason to believe that his acts constituted an infringement of copyright," is sufficient to protect against unwarranted liability in cases of occasional or isolated innocent infringement, and it offers adequate insulation to users, such as broadcasters and newspaper publishers, who are particularly vulnerable to this type of infringement suit. On the other hand, by establishing a realistic floor for liability, the provision preserves its intended deterrent effect; and it would not allow a defendant to escape simply because the plaintiff failed to disprove his claim of innocence.

Id

76. Id. 
broadcasters to take chances on new works by withholding any undue punishment from the 1976 Act.

Downstream infringement of this nature casts a wide net. Millions of customers could incur liability because they purchased and downloaded a song whose musical composition infringed on another's work. For example, suppose Caliber wins his infringement lawsuit against 50 Cent. Caliber would then have claims against both retail outlets-brick-and-mortar and online-for unauthorized distribution of an unauthorized adaptation of Caliber's song ${ }^{77}$ and every consumer who purchased a download of the song through the online retailers for unauthorized reproduction. ${ }^{78}$

Individually suing every consumer who downloaded "I Get Money" would be onerous; the song sold over two million copies. ${ }^{79}$ With such a multitude of defendants for a single song, a copyright owner such as Caliber might seek to certify all of the purchasers of an infringing song as a defendant class. ${ }^{80}$ A defendant class action occurs when a plaintiff "name[s] a defendant representative to defend the interests of a class of unnamed potential defendants." ${ }^{1}$ While rare, suits involving classaction defendants have been certified. ${ }^{82}$

77. 17 U.S.C. § 106(3).

78. Id. § 106(1).

79. See supra notes $35-36$ and accompanying text.

80. A "class action" suit is one

in which the court authorizes a single person or a small group of people to represent the interests of a larger group; [specifically, it is] a lawsuit in which the convenience either of the public or of the interested parties requires that the case be settled through litigation by or against only a part of the group of similarly situated persons and in which a person whose interests are or may be affected does not have an opportunity to protect his or her interests by appearing personally or through a personally selected representative, or through a person specially appointed to act as a trustee or guardian.

BLACK'S LAW DICTIONARY 284 (9th ed. 2009).

81. James M. Underwood, Road to Nowhere or Jurisprudential U-Turn? The Intersection of Punitive Damage Class Actions and the Due Process Clause, 66 WASH. \& LEE L. REV. 763, 780 n.96 (2009) (citing FED. R. CIV. P. 23(a)). This form of class action has its origins in English Chancery courts' bills of peace "where a plaintiff sued several defendants as a class." Nelson Rodrigues Netto, The Optimal Law Enforcement with Mandatory Defendant Class Action 33 U. DAYTON L. REV. 59, 77 (2007). A bill of peace "could resolve a controversy between an individual, the adversary, and several persons (called the multitude), where there were common questions of law or fact, or both, involving each and every one of them, and where there was no basis for a party joinder under the common law.” Id. at 77 n.55.

82. See, e.g., ASARCO Inc. v. Kadish, 490 U.S. 605, 610 (1989) (noting certification of case as a defendant class action); Broad. Music, Inc. v. Columbia Broad. Sys., Inc., 441 U.S. 1, 4 n.1 (1979) (noting the district court's certification of the case) (citing 400 F. Supp. 737, 741 n.2 (S.D.N.Y. 1975)); In re Integra Realty Res., Inc., 354 F.3d 1246, 1264 (10th Cir. 2004) (affirming certification of case as a defendant class action). 
A copyright owner such as Caliber would have to meet the requirements of Rule 23 under the Federal Rules of Civil Procedure, which provides:

One or more members of a class may sue or be sued as representative parties on behalf of all members only if:

(1) the class is so numerous that joinder of all members is impracticable;

(2) there are questions of law or fact common to the class;

(3) the claims or defenses of the representative parties are typical of the claims or defenses of the class; and

(4) the representative parties will fairly and adequately protect the interests of the class. ${ }^{83}$

In addition, Rule 23(b) specifies the types of class actions that "may be maintained if Rule 23(a) is satisfied."

If Caliber were to file a suit against a class of defendants, a court may, in fact, certify the class. ${ }^{85}$ First, the class could have over one million members; therefore, joinder of all members would be impracticable. Second, the questions of law or fact are common to all the members of the class - all class members downloaded a song from a music retailer's website. Third, the questions of law or factinfringement based on downloading an infringing song-are common to the class, as are the claims or defenses of the representative parties. The prong that creates the most difficulty for Caliber is the requirement that those individuals whom he chooses to be "the representative parties fairly and adequately protect the interests of the class." 6 Caliber would

83. FED. R. CIV. P. 23(a) (emphasis added); see also Labrador v. Seattle Mortg. Co., No. 082270 SC, 2010 WL 3768378, at *3 (N.D. Cal. Sept. 22, 2010) (setting out legal standard for class certification).

84. FED. R. CIV. P. 23(b).

85. A court would most likely certify the class under Rule 23(b)(3), which allows class-action certification when "the court finds that the questions of law or fact common to class members predominate over any questions affecting only individual members, and that a class action is superior to other available methods for fairly and efficiently adjudicating the controversy."

A Rule 23(b)(1)(A) class may also be appropriate, however, where individual actions may cause "inconsistent or varying adjudications with respect to individual class members that would establish incompatible standards of conduct for the party opposing the class."

86. FED. R. CIV. P. 23(a)(4). 
also have to contend with the notice requirements; ${ }^{87}$ this may be achieved, however, by subpoenaing the online music retailer's records, which should contain the names and addresses of customers who purchased the song.

The class members who do not opt out would be represented by the class counsel, ${ }^{88}$ who would likely claim "innocent infringement," which, if successful, could reduce statutory damages from $\$ 750$ per defendant to $\$ 200$ each. $^{89}$ It is unlikely that a single defendant would hire an attorney to have her damages reduced by $\$ 550$; therefore, class certification may be in the best interest of the defendants in terms of reducing their monetary liability. ${ }^{90}$

Should Caliber succeed in his class action suit, he would need to collect the statutory damages from all of the members of defendant class. Caliber has already acquired the names and addresses of all those persons who purchased and downloaded the infringing song for the purposes of serving notice. After a court enters judgment in favor of Caliber, he could probably seek a court order directing the online retailer to charge the statutory damages to the defendant class members' credit cards. It is unclear whether this would be successful.

Large record producers may be hesitant to alienate their customers by filing infringement actions against them. But an individual musician could see such an action as his "meal ticket." The musician may never have a hit song himself, but could "hit the lottery" by suing the one million customers who downloaded a hit song that had infringed his copyright.

\section{B. Musicians as Inducers?}

A musician who has created an infringing musical work and made a sound recording of that work available for download might also face third-party-infringement liability through the doctrines of vicarious

\footnotetext{
87. If a court were to certify under Rule 23(b)(1) or 23(b)(2), then "the court may direct appropriate notice to the class.” FED. R. CIV. P. 23(c)(2). For a class certification under Rule 23(b)(3), "the court must direct to class members the best notice that is practicable under the circumstances, including individual notice to all members who can be identified through reasonable effort." Since Caliber would likely subpoena the contact information from the online retailer, individual notice to all members would be possible.

88. FED. R. CIV. P. 23(g).

89. See 17 U.S.C. $\S 504(c)(2)$ (2006).

90. If Caliber were to certify one million defendants in the class, then the court could reduce the damages from $\$ 750$ million to $\$ 200$ million.
} 
liability, contributory infringement, and inducement. ${ }^{91}$ Of course, a direct infringement must precede an indirect infringement-in the situation at hand, this is the consumer who downloads the infringing song. In our example, 50 Cent may not only have direct-infringement liability, but the distribution by the online retailers and downloading of his song by customers - both of whom are direct infringers-may subject him to third-party liability.

To prove vicarious liability, Caliber would need to show that 50 Cent "ha[d] the right and ability to supervise the infringing activity and also ha[d] a direct financial interest in such activities." 92 50 Cent had the right and ability to stop the infringing activity by removing his song from the retail websites. And he had a financial interest in the infringing activity - he stands to profit from every online sale and download of the infringing song.

50 Cent may also be liable for contributory infringement if, "with knowledge of the infringing activity, [he] induce[d], cause[d,] or materially contribute[d] to the infringing conduct of another." ${ }^{\text {"93 }} 50$ Cent would know about the infringing activity-downloading the songsbecause he is aware that the songs are available for sale online. After all, he-or his agents-negotiated with the online retailer for the song's presence on the website for sale and download. By this same reasoning, 50 Cent would also have materially contributed to the consumers' infringing conduct. In fact, it was his purpose to have the song purchased by the general public, even if he did not consider such purchases to be infringing activities. On the other hand, Caliber would face some difficulty proving that 50 Cent induced customers to infringe Caliber's copyright, no different from his attempts to show that 50 Cent induced a brick-and-mortar record store to infringe. ${ }^{94}$

Just like a brick-and-mortar store, an online music retailer, such as iTunes or Amazon.com, would face infringement liability as the

91. See supra notes 44-49 and accompanying text.

92. Gershwin Publ'g Corp. v. Columbia Artists Mgmt., Inc., 443 F.2d 1159, 1162 (2d Cir. 1971) (citing Shapiro, Bernstein \& Co. v. H. L. Green Co., 316 F.2d 304 (2d Cir. 1963); Case Note, Television Sponsor and Advertising Agency Held Vicariously Liable for Copyright InfringementDavis v. E. I. DuPont de NeMours \& Co., 64 MiCH. L. REV. 1172, 1175-78 (1966)); see also Fonovisa, Inc. v. Cherry Auction, Inc., 76 F.3d 259, 262 (9th Cir. 1996) (quoting Gershwin Publ'g, 443 F.2d at 1162).

93. Gershwin Publ'g, 443 F.2d at 1162 (footnote omitted) (citing Fortnightly Corp. v. United Artists Television, Inc., 392 U.S. 390, 396-97 (1968)).

94. See supra notes $47-49$ and accompanying text. 
distributors of an infringing musical work. ${ }^{95}$ One could argue that the sale by the online music retailer and the purchase and download by the consumer is one act of infringement; however, these could also be considered two separate acts of infringement. The 1976 Act provides:

[T] he copyright owner may elect... to recover, instead of actual damages and profits, an award of statutory damages for all infringements involved in the action, with respect to any one work, for which any one infringer is liable individually, or for which any two or more infringers are liable jointly and severally .... ${ }^{96}$

Therefore, if the act of purchasing and downloading the song from an online music retailer comprises a single infringement, then the consumer and the retailer would incur joint and several liability; the plaintiff musician would not be able to collect from both defendants. ${ }^{97}$ If, however, the distribution by the online music retailer and the copying by the customer constitute two separate acts of infringement, then the plaintiff musician could collect separately from each defendant.

Unlike a brick-and-mortar store, however, an online music retailer may seek protection under the safe-harbor provision in the Digital Millennium Copyright Act (DMCA), which would provide immunity

95. See supra note 43 and accompanying text.

96. 17 U.S.C. § 504(c)(1) (2006); see also U.S. Media Corp. v. Edde Entm’t Corp., No. 94 CIV. 4849(MBM)MHD, 1998 WL 401532, at *8 (S.D.N.Y. July 17, 1998). "If several defendants participate in a transaction or series of transactions that brings about [a copyright] infringement, they will be held jointly and severally liable for plaintiff's lost profits.” U.S. Media, 1998 WL 401532, at *8 (citing Abeshouse v. Ultragraphics, Inc., 754 F.2d 467, 472 (2d Cir. 1985); MCA, Inc. v. Wilson, 677 F.2d 180, 186 (2d Cir. 1981)). However, the defendants in U.S. Media were suppliers, distributors, and retailers of a single infringing product - there were no defendant consumers. Id. at *1. Cf. Bouchat v. Champion Prods., Inc., 327 F. Supp. 2d 537, 553 (D. Md. 2003) (holding that a plaintiff would be entitled to a single statutory damages award for which the primary infringer would be jointly and severally liable with derivative infringers).

97. Under the tort theory of joint and several liability, "each liable party is individually responsible for the entire obligation, but a paying party may have a right of contribution and indemnity from nonpaying parties.” BLACK'S LAW DICTIONARY 997 (9th ed. 2009). See also McDermott, Inc. v. AmClyde, 511 U.S. 202, 220-21 (1994) (“Joint and several liability applies when there has been a judgment against multiple defendants. It can result in one defendant's paying more than its apportioned share of liability when the plaintiff's recovery from other defendants is limited by factors beyond the plaintiff's control, such as a defendant's insolvency. When the limitations on the plaintiff's recovery arise from outside forces, joint and several liability makes the other defendants, rather than an innocent plaintiff, responsible for the shortfall” (citing Edmonds v. Compagnie Generale Transatlantique, 443 U.S. 256, 271-71 (1979))). 
from monetary liability. ${ }^{98}$ But this would most likely fail because of the inapplicability of several requisite conditions.

First, an online music retailer would have to qualify as a "service provider" " by showing it is "a provider of online services or network access, or the operator of facilities therefor."100 The online music retailer likely falls under the category of "a provider of online services," thus meeting the definition.

Section 512(c) provides the most plausible safe harbor for an online music retailer, limiting liability for service providers with "[i]nformation residing on systems or networks at direction of users."101 Per subsection (c)(1), “[a] service provider shall not be liable for monetary relief . . . for infringement of copyright by reason of the storage at the direction of a user of material that resides on a system or network controlled or operated by or for the service provider" if certain conditions are met. The service provider - in this instance, the online music retailer-cannot "have actual knowledge that the material or an activity using the material on the system or network is infringing." "102 One must first identify the "infringing activity" - options include the unauthorized adaptation of a musical composition or the unauthorized distribution of the unauthorized adaptation of the musical composition. Obviously, an online music retailer would argue that it is the former, and a plaintiff would argue that it is the latter. ${ }^{103}$ The online music retailer and the musician likely agreed, however, that the retailer would store the digital file of the sound recording on its server, enable customers to purchase copies of the digital file for downloading, and receive a percentage of the sales. The website is not merely an enabler or a repository of files. Additionally, it voluntarily enters into agreements with musicians whereby it will distribute phonorecords of sound recordings; thus, it infringes the

98. Pub. L. No. 105-304, § 202(a), 112 Stat. 2860, 2877-86 (1998) (codified as amended at 17 U.S.C. § 512(c) (2006)).

99. 17 U.S.C. § 512(c)(1).

100. Id.

101. Id. § 512(c). Section 512(a) applies to "[t]ransitory digital network communications"; § 512(b) creates immunity for system caching; and § 512(d) provides a safe harbor for search engines. None of these applies in this example.

102. Id. § 512(c)(1)(A)(i).

103. If the infringing activity is determined to be merely the unauthorized adaptation, then the online music retailer is not a direct infringer and is eligible for the safe harbor. If, however, the infringing activity is the unauthorized distribution, then the online music retailer is a direct infringer and thus ineligible for the safe harbor. 
copyright. Finally, the music retailer selects the material appearing on its website. $^{104}$

The safe-harbor provision further requires that the provider of online services " $\mathrm{d}[\mathrm{id}]$ not receive a financial benefit directly attributable to the infringing activity, in a case in which the service provider ha[d] the right and ability to control such activity." ${ }^{\prime 05}$ An online music retailer would fail this requirement as well. The retailer profits off the download and has the ability to control the infringing activity - that is, the retailer has the ability to remove the infringing song file from its website and not make it available for download. ${ }^{106}$

Therefore, the fact that an online music store actively chooses the material it sells and reaps a direct financial benefit from the sale of the MP3 files may remove any hope of a safe harbor. It incurs the same liability a brick-and-mortar store incurs; indeed, Apple has already faced lawsuits for this form of infringement. ${ }^{107}$ As for a musician's vicarious liability due to the actions of the online music store, it is also the same as it would be in the brick-and-mortar situation discussed previously. ${ }^{108}$

\section{HOW FAR DOWNSTREAM DO WE LOOK FOR INFRINGERS?}

Public policy discourages liability for downstream infringement. In several instances, Congress has specifically created statutory exemptions for infringing uses by end-users of patented technology. For example, if a medical practitioner performs a medical activity-such as a patented surgical technique-that constitutes an infringement under the Patent Act, neither the "infringing" medical practitioner nor the hospital or facility that accommodated the surgery will face the provisions imposing the remedies, injunctions, damages, and attorney's fees. ${ }^{109}$

Downstream liability in patent law has also required notice of the patent. "[W]here a patent is sold as a commercial product, an alleged infringer is deemed to have 'constructive notice' of the patent protection

104. See, e.g., Ethan Smith, Apple Finally Shares Beatles, WALl ST. J., Nov. 16, 2010, at B1 (noting Apple's success in obtaining the rights to sell the Beatles' catalog on iTunes).

105. 17 U.S.C. § 512(c)(1)(B).

106. The final requirement, contained in $\S 512(\mathrm{c})(1)(\mathrm{C})$, is also immaterial to our discussion as it deals with the "service provider's" response upon notification of infringing activity.

107. Tuan Nguyen, Apple Sued for Artistic Copyright Infringement, DAILYTECH (July 5, 2007, 4:10 PM), http://www.dailytech.com/Apple+Sued+for+Artistic+Copyright+Infringement/article 7933.htm.

108. See supra notes $44-49$ and accompanying text.

109. 35 U.S.C. § 287(c)(1) (2006). 
'when the patentee consistently mark[s] substantially all of its patented products' with the statutory label."110 If the items are not marked with the patent number, or the mark is removed by an upstream seller, and then "reintroduce[d] into the stream of commerce, [this action of removing the mark] effectively immuniz[es] all subsequent purchasers from . . . infringement damages." 111

In the case of the downstream consumer who is unaware of the original copyright infringement by the defendant-musician, copyright law could embrace patent-law doctrines regarding end-user immunity and lack of notice. ${ }^{112}$ Just like the ignorant downstream user of infringing patented technology, the purchasers of infringing songs could be considered too far removed to be foreseeable defendants. ${ }^{113}$

One must also question whether the mode of purchase should affect a consumer's liability for copyright infringement. As noted earlier, purchasing a physical embodiment—such as a CD or vinyl record-does not impose copyright-infringement liability on the consumer. ${ }^{114}$ To declare that this same activity-changed only by how the copyrighted work is fixed-now results in infringement seems grossly unjust. Instead, "fundamental notions of fairness and legal process"115 should dictate that the same rules apply to both brick-and-mortar transactions and online purchases of music.

This unforeseen downstream-infringement liability could have serious ramifications-pursuing consumers who believe they are legally acquiring copies of songs could lead to unintended consequences regarding the downloading and purchasing habits of the public. It could

110. Syngenta Seeds, Inc. v. Delta Cotton Co-op., Inc., 457 F.3d 1269, 1276 n.2 (Fed. Cir. 2006) (alteration in original) (quoting Sentry Prot. Prods., Inc. v. Eagle Mfg. Co., 400 F.3d 910, 918 (Fed. Cir. 2005)).

111. Id.

112. When faced with similar circumstances, policies and concepts from one area of intellectualproperty law are often adopted by another. See, e.g., Sony Corp. of Am. v. Universal City Studios, Inc., 464 U.S. 417, 434-35 (1984) (borrowing the express language in the Patent Act regarding third party liability to similarly impose "liability for copyright infringements on certain parties who have not themselves engaged in the infringing activity,” namely vicarious liability and contributory infringement).

113. Similarly, in negligence law, Mrs. Palsgraf was unable to obtain any relief after being injured on a train platform by an exploding package because she was an unforeseeable victim too far removed from the act of negligence to receive relief in the courts. Palsgraf v. Long Is. R.R., 248 N.Y. 339, 346-47 (1928) (Cardozo, C.J.). For a plaintiff to prevail on a claim of negligence, "[t]he damages must be so connected with the negligence that the latter may be said to be the proximate cause of the former.” Id. at 351 (Andrews, J., dissenting).

114. See supra notes $41-42$ and accompanying text.

115. Am. Trucking Ass'ns, Inc. v. Smith, 496 U.S. 167, 212 (1990) (Stevens, J., dissenting). 
push people toward illegal download sites-after all, why do the right thing and pay for a legal download if one can still be sued? A consumer may think that if he could be held liable for infringement because of the conduct of a musician, he might as well just download songs for free in an unauthorized transaction and make it more difficult to get caught. After all, a transaction on iTunes is easier to trace-the website has the customer's name, address, and credit card information. For the illegal download, a plaintiff may face a more difficult—if not impossible-task of tracking down those individuals who use infringing peer-to-peer downloading software. ${ }^{116}$ "More than one computer may be placed under a single [Internet Protocol (IP) address]. Thus, it is possible that the [Internet Service Provider (ISP)] may not be able to identify with any specificity which of numerous users" who are attached to a specific IP address at the time of the unauthorized download is the one who allegedly infringed. ${ }^{117}$ Under such circumstances, providing the plaintiffs with "a long list of possible infringers would" impermissibly lead to a "fishing expedition.","118

\section{CONTEMPLATING SOLUTIONS}

As noted earlier, many reasons support protecting online purchasers from downstream liability when the downloaded song infringes a

116. London-Sire Records, Inc. v. Doe 1, 542 F. Supp. 2d 153, 178 (D. Mass. 2008) (noting that when determining whether to grant a subpoena requesting the name, address, and other information attached to an IP address, "the Court must consider whether the information sought can be reasonably traced to a particular defendant”); Lemley \& Reese, supra note 17 , at 5 (“[T] owner would need to provide evidence showing that the particular IP address in question was, at the time in question, assigned to the person against whom the dispute is brought.”).

117. London-Sire Records, 542 F. Supp. 2d at 178.

118. Id. In Sony Music Entertainment Inc. v. Does 1-40, the United States District Court for the Southern District of New York laid out a test for "evaluating subpoenas seeking identifying information from ISPs regarding subscribers who are parties to litigation.” 326 F. Supp. 2d 556, 564-65 (S.D.N.Y. 2004). Factors to weigh in balancing

the need for disclosure against First Amendment interests. . . include: (1) a concrete showing of a prima facie claim of actionable harm; (2) specificity of the discovery request; (3) the absence of alternative means to obtain the subpoenaed information; (4) a central need for the subpoenaed information to advance the claim; and (5) the party's expectation of privacy.

Id. (citations omitted). The district court designed the test to avoid a "fishing expedition" by plaintiffs. London-Sire Records, 542 F. Supp. 2d at 178; see also Boag, supra note 19, at 243-44 (discussing the privacy issues involved in subpoenaing ISPs for personal information of possible defendants). 
copyright. While courts could provide such protection, Congress should amend the 1976 Act.

\section{A. Is This Something the Courts Can Resolve?}

Courts faced with consumer-infringement litigation may wish to borrow the downstream-infringement doctrine from patent law and, in this manner, limit consumer liability. ${ }^{119}$ It may be considered legislating from the bench for courts to decide that this is a non-infringing use and hold that the rights granted to copyright owners under the 1976 Act do not include this kind of downstream activity; indeed, the First Circuit has held that there was no such exception in the 1976 Act. ${ }^{120}$ The court noted that while Congress made express exceptions to infringement liability for solely personal and non-commercial use in the 1976 Act, it had not done so for music downloading. ${ }^{121}$

As a second option, customers in a copyright-infringement action could rely on jury nullification ${ }^{122}$ and hope that juries simply refuse to impose liability for infringement under these circumstances. It would be very risky, however, to rely on a jury's taking such action.

Third, a consumer who incurs infringement liability for downloading songs that she reasonably believed to be non-infringing may convince a judge that statutory damages violate constitutional due process or common law excessiveness. The constitutional issue regarding excessiveness is unresolved. Recently, in Sony BMG Music Entertainment v. Tenenbaum, the First Circuit reversed a lower court's finding that a jury's imposition of $\$ 675,000$ in statutory damages for the downloading of thirty songs violated the defendant's constitutional right against a jury award as " "grossly excessive, inordinate, shocking to the conscience of the court, or so high that it would be a denial of justice to permit it to stand.",123 The appellate court found that the constitutional

119. See supra notes 109-12 and accompanying text.

120. Sony BMG Music Entm’t v. Tenenbaum, Nos. 10-1883, 10-1947, 10-2052, 2011 WL 4133920, at *9-12 (1st Cir. Sept. 16, 2011).

121. Id. at $* 10$.

122. Jury nullification can be defined as "render[ing] an acquittal... in disregard of the governing law and the weight of the evidence.” Paula L. Hannaford-Agor \& Valerie P. Hans, Nullification at Work? A Glimpse from the National Center for State Courts Study of Hung Juries, 78 CHI.-KENT L. REV. 1249, 1249 (2003).

123. 2011 WL 4133920, at *19, 21 (quoting Correa v. Hosp. S.F., 69 F.3d 1184, 1197 (1st Cir. 1995)). For further reading regarding the constitutionality of copyright statutory damages, see Colin Morrissey, Note, Behind the Music: Determining the Relevant Constitutional Standard for Statutory 
issue was decided prematurely, ${ }^{124}$ and that before considering "whether the award violated due process[,] . . . [t]he district court should first have considered the non-constitutional issue of remittitur, which may have obviated any constitutional due process issue." 125 The appellate court "reinstate[d] the jury's award of damages" ${ }^{\prime 26}$ and remanded to the lower court "for consideration of defendant's motion for common law remittitur based on excessiveness." ${ }^{127}$ In our example, if a court upholds a judgment of damages against the defendant class, or Caliber accepts a remittitur, he would then have the task of collecting damages from the one million defendants. ${ }^{128}$

\section{B. Or Does This Require a Legislative Solution?}

Courts have repeatedly stated that despite a law's harsh and unintended consequence, judges should refrain from legislating from the bench. ${ }^{129}$ Thus, beyond the reduced statutory damages provided for when "innocent infringement" has been proven to the satisfaction of the court, action by Congress may be the prudent way to provide protection for downstream consumers caught in this web.

Any amendment to the 1976 Act that protects consumers in this manner should be carefully worded so as to only cover downloads of music for which there is a reasonable belief that the musical composition in the sound recording fixed in the phonorecord does not infringe on any other musical composition. Three alternatives could achieve this. The first creates an exemption to infringement; the second and third amend § 504(c)(2) of the 1976 Act regarding statutory damages. One alternative to the $\S 504$ amendment gives the courts discretion to reduce damages

Damages in Copyright Infringement Lawsuits, 78 FORDHAM L. REV. 3059 (2010).

124. Tenenbaum, 2011 WL 4133920, at *21.

125. Id. at $* 19$.

126. Id. at $* 25$.

127. Id. The appellate court noted that "[i]f, on remand, the court allows any reduction through remittitur, then plaintiffs must be given the choice of a new trial or acceptance of remitter." Id.

128. As discussed earlier, it is unclear whether this collection method would be allowed. See supra Part III.A.

129. See, e.g., Exxon Mobil Corp. v. Allapattah Servs., Inc. 545 U.S. 546, 565 (2005) (“[I]t is up to Congress rather than the courts to fix [unintentional drafting gaps]."); United States v. Hopkins, 427 U.S. 123, 125 (1976) (per curiam) (“' [I]t is up to Congress to remedy this apparent harsh result.... [T] he courts should refrain from legislating by judicial fiat."”) (second alteration in original) (quoting Keetz v. United States, 168 Ct. Cl. 205, 207 (1964) (per curiam), superseded by statute, Tucker Act Amendment of 1970, Pub. L. 91-350, § 1(b), 84 Stat. 449, as recognized by Slattery v. United States, 635 F.3d 1298, 1324 (Fed. Cir. 2011) (en banc)). 
even further than the $\$ 200$ minimum now allowed. The other shifts the burden to the plaintiff to show "non-innocent" infringement by the consumer, and innocent infringement would again lead to discretionary damages.

\section{Legislatively Providing for Another Exception to Infringement Under the 1976 Act}

This first alternative exempts downstream consumers from infringement. There are already several exceptions to the rights granted in $\S 106$, including exceptions for fair use, ${ }^{130}$ transfer of a lawful copy, ${ }^{131}$ and secondary transmissions. ${ }^{132}$ One could analogize the creation of a bright-line exception for consumer downloads to the exception end receivers of a program received through a secondary transmission under $\S 111$ of the 1976 Act - when watching a favorite television show, one assumes that the transmission was lawfully obtained by the cable or satellite company from the broadcaster. In the situation outlined in this Article, the consumer has a good-faith belief that the download purchased from the online music store is an authorized phonorecord of the sound recording and underlying musical composition. In the alternative, rather than completely exempting downstream consumers from liability, Congress could set the statutory damages for this situation to a nominal amount.

Providing an exception to infringement for consumers would create a bright-line rule for removing this unintended form of infringement. "In deciding whether to adopt a bright-line rule or a loose standard, the Supreme Court has considered who will need to apply the legal rule, and in what context." ${ }^{133}$ The Fifth Circuit has noted that:

[W]hen lines are drawn sufficiently sharp in their definitional edges to be reasonable and predictable, such differing results are the inevitable result-indeed, decisions are the desired product.... [B]y making results more predictable, [bright line rules] serve[] a normative

\footnotetext{
130. 17 U.S.C. § 107 (2006).

131. Id. § 109.

132. Id. § 111.

133. Jesse Leigh Jenike-Godshalk, Note, Appealed Denials and Denied Appeals: Finding a Middle Ground in the Appellate Review of Denials of Summary Judgment Following a Full Trial on the Merits, 78 U. CIN. L. REV. 1595, 1620 (2010).
} 
function. [They] operate[] as a rule of law and allow[] a court to adjudicate rather than manage. ${ }^{134}$

A bright-line rule "has the virtue of predictability with the vice of creating results in cases at its edge that are said to be 'unjust' or 'unfair.,"'135 As a disadvantage, bright-line rules can lead to "seemingly perverse results." 136 For example, consumers caught up in the web of the two musicians involved in an infringement suit over a copyrighted song currently fall on the infringement side of a bright line, which turns them into unintended downstream infringers - this can be viewed as a perverse result of this bright line of strict liability. ${ }^{137}$ Another bright-line rule excepting this behavior from infringement liability may be the appropriate remedy.

\section{Amending the Statutory Damages Provision Under $\S 504$ to Provide} for Greater Judicial Discretion

This second option amends the provision regarding statutory damages - specifically $\S 504(\mathrm{c})(2)^{138}$ — to provide greater judicial discretion regarding remedies. Congress could enact legislation providing for one of several alternatives. Courts could (1) receive authority to absolve the defendant of any monetary liability; (2) retain the discretion to limit damages to a nominal amount; or (3) require only that the innocent infringer delete all copies of the infringing song file. Such discretion would provide consumers with some sense of relief and certainty that, should they face infringement claims, the court may reduce or eliminate any liability for monetary damages.

134. Louisiana ex rel. Guste v. M/V Testbank, 752 F.2d 1019, 1029 (5th Cir. 1985) (en banc) (citing Lon L. Fuller, The Forms and Limits of Adjudication, 92 HARV. L. REV. 353, 396 (1978)).

135. Id.; see also Elizabeth Cosenza, Dura-tion: A New Paradigm for Construing the Statute of Limitations in Securities Fraud Class Actions, 62 BAYLOR L. REV. 681, 724, 725 (2010) (arguing that the Supreme Court has an "interest in promoting judicial economy and certainty in the law through the application of a bright-line rule of liability" because it "eases the burden on the judiciary and offers predictive value to those who provide services to participants in the securities business").

136. $M / V$ Testbank, 752 F.2d at 1029.

137. Faulkner v. Nat'l Geographic Soc’y, 576 F. Supp. 2d 609, 613 (S.D.N.Y. 2008) (citing E. Am. Trio Prods., Inc. v. Tang Elec. Corp., 97 F. Supp. 2d 395, 415 (S.D. N.Y. 2000)) (noting that copyright infringement is a tort of strict liability).

138. 17 U.S.C. $§ 504(c)(2)$ (2006) ("In a case where the infringer sustains the burden of proving, and the court finds, that such infringer was not aware and had no reason to believe that his or her acts constituted an infringement of copyright, the court in its discretion may reduce the award of statutory damages to a sum of not less than $\$ 200 . ”)$. 
One must bear in mind, however, that "as is always the case when an issue is committed to judicial discretion, the judge's decision must be supported by a circumstance that has relevance to the issue at hand.”139 Justice Ginsberg has "observed that 'unlimited jury [or judicial] discretion ... may invite extreme results that jar one's constitutional sensibilities." 140 Thus, the downside to legislating greater judicial discretion regarding statutory damages is the possibility of extreme results unintended by Congress.

In addition, "workability is a fundamental concern for any legal standard or test." 141 Any statutorily granted judicial discretionary allowance would need to be workable by the courts. One of the difficulties of providing for greater judicial discretion "is that it often requires difficult factual inquiries and subjective policy judgments which are more appropriate for legislative, rather than judicial, determination." 142

Also, a judge's reduction of damages still requires a trip to the courthouse by the downstream consumer, and it may be easier to settle than to hope that a sympathetic judge hears the case. Legal fees would accrue even if the defendant is successful, and a settlement may occur regardless. Thus, providing for judicial discretion regarding damages may not eliminate the threat of potential collateral damage of deterring consumers from legally downloading new music.

3. Amending the Statutory Damages Provision Under § 504 to Shift the Burden of Proof

A third alternative would be for Congress to amend § 504 to shift the burden of proof regarding innocent infringement from defendant to plaintiff. Currently, the onus is on the defendant to prove innocent infringement. ${ }^{143}$ In the case of a consumer downloading a song from a website that was authorized to sell the song from the defendant-musician, however, the burden could instead shift to the plaintiff to prove "non-

139. City of Milwaukee v. Cement Div., Nat'l Gypsum Co., 515 U.S. 189, 196 n.8 (1995) (citing Henry J. Friendly, Indiscretion About Discretion, 31 EMORY L.J. 747 (1982)).

140. State Farm Mut. Auto. Ins. Co. v. Campbell, 538 U.S. 408, 430 (2003) (Ginsberg, J., dissenting) (alteration in original) (quoting Pac. Mut. Life Ins. Co. v. Haslip, 499 U.S. 1, 18 (1991)).

141. Jenike-Godshalk, supra note 133, at 1620. Despite disadvantages, "a bright-line rule may be preferable. Even for trained legal professionals, some tests may be so complicated or unclear that they do not provide enough guidance or that they even become unworkable." Id.

142. Linseman v. World Hockey Ass’n, 439 F. Supp. 1315, 1320 (D. Conn. 1977).

143. 17 U.S.C. $\S 504(c)(2)$. 
innocent” infringement. If Congress chose to enact one or several of the other alternatives discussed in Part V.B as well, then a plaintiff's failure to meet his burden of proof could lead to either zero or negligible monetary damages.

Shifting the burden of proof would mean that the plaintiff would have a higher overall hurdle to meet for downstream consumers who purchase infringing songs. ${ }^{144}$ This may parallel the initial burden placed on copyright owners proceeding with take-down requests under the DMCA. In Lenz v. Universal Music Corp., the court found that in order for a copyright owner to proceed with a take-down notice under the DMCA, there must be "'a good faith belief that use of the material in the manner complained of is not authorized by the copyright owner, its agent, or the law' [and] the owner must evaluate whether the material makes fair use of the copyright." "145 Similarly, in order to collect more than nominal damages, the statute could require a plaintiff suing consumers for downloading an infringing song from an online music retailer to show that the consumer's actions were not those of an "innocent infringer." The plaintiff-musician would still have a claim against the infringing musician for every downloaded song, as well as against the online music retailer, but both of these defendants have greater resources at their disposal and are more cognizant of the risks than the downstream consumer. Additionally, the online music retailer and the infringing musician are in a better position to negotiate for the possibility of an infringement lawsuit by the copyright owner regarding the alleged infringement. ${ }^{146}$

Both allowing for more judicial discretion in awarding damages and shifting the burden of "innocent infringement" to the plaintiff, however, could lead to forum shopping and inconsistent results in different jurisdictions. Some jurisdictions may be more inclined to find in favor of consumer defendants and others less likely. Our system of justice seeks to discourage forum shopping and avoids inequitable

144. For a general discussion of this burden-shifting for a determination of non-fair use for effective DMCA notices, see Benjamin Wilson, Notice, Takedown, and the Good-Faith Standard: How to Protect Internet Users from Bad-Faith Removal of Web Content, 29 ST. LOUIS U. PUB. L. REV. 613 (2010).

145. Lenz v. Universal Music Corp., 572 F. Supp. 2d 1150, 1154 (N.D. Cal. 2008) (quoting 17 U.S.C. § 512(c)(3)(A)(v)).

146. For example, an online music retailer may decide to negotiate for an indemnification clause in its agreement with musicians who wish to sell songs on the website. 
administration of the law. ${ }^{147}$ This burden-shifting approach may resolve the issue, but could also result in undesired consequences.

Of the options discussed above- both judicial and legislativewhich one is the recommended approach? All have pros and cons associated with them. As noted previously, leaving it to the courts to declare that consumers were not intended infringers or to sua sponte reduce damages below the statutory minimums are not prudent solutions. A court will not wish to disturb a jury's finding. Indeed, hoping for a solution in the courts could also lead to bullying by the copyright owner through the threat of a lawsuit-a consumer is more likely to settle with the copyright owner than defend the suit in court.

Therefore, sensible courses of action include adding an exemption to infringement liability under $\S 501$ of the 1976 Act or amending $\S 504$ to reduce or eliminate liability for monetary damages.

\section{CONCLUSION}

While some musicians may pursue consumers for this form of infringement, many others may not. Some artists see any use of their music by someone other than themselves as unacceptable, ${ }^{148}$ while others may choose to only seek remuneration from the infringing musician. Music downloading has become the dominant way to purchase songs, and with so many consumers who could be affected, inconsistent enforcement could have a profound and widespread effect that extends beyond copyright law. Inconsistent enforcement against downstream consumer infringers could weaken our overall fidelity to the law. In addition, if infringement suits are brought against defendants who believe they are lawfully downloading songs, consumers may see little difference-and less risk-in downloading a song legally versus illegally. ${ }^{149}$ Taken to an extreme, this seemingly absurd form of infringement litigation could erode some basic tenets of our societynamely our respect for the rule of law.

147. See Hanna v. Plumer, 380 U.S. 460, 467-68 (1965).

148. For example, Prince is notorious in his attempts to control any and all uses of his music. See Lenz, 572 F. Supp. 2d at 1152. "Prince [has] spoke[n] publicly about his efforts 'to reclaim his art on the internet' and threatened to sue several internet service providers for alleged infringement of his music copyrights." Id. (citing Mike Collett-White, Prince to Sue YouTube, eBay Over Music Use, REUTERS, Sept. 13, 2007, http://www.reuters.com/article/2007/09/14/us-prince-youtubeidUSL1364328420070914? fepdtype=RSS\&FeedName_InternetNews\&rpc=22\&sp=true).

149. See supra Part IV. 
In his article, Changes in American Veneration for the Rule of Law, James Gibson posits that Americans firmly support the rule of law as crucial for an effective democracy. ${ }^{150}$ He notes that consistency is at the heart of this concept:

Where power is arbitrary, personal, and unpredictable, the citizenry will not know how to behave; it will fear that any action could produce an unforeseen risk. Essentially, the rule of law means: (1) that people ... will be treated equally by the institutions administering the law-the courts, the police, and the civil service; and (2) that people and institutions can predict with reasonable certainty the consequences of their actions, at least as far as the state is concerned. ${ }^{151}$

"But the rule of law is more than a set of institutions, a constitution, or a book of statutes. Indeed, perhaps [its] most important manifestation ... is its representation in a nation's culture-the beliefs, expectations, values, and attitudes held by [a country's citizens]."152 Indeed, Gibson points to Professor Martin Krygier's admonition that the rule of law holds manifest and fundamental importance based on "“a widespread assumption within society that law matters and should matter.",153 As a society, we abhor regimes in which arbitrary laws are created and administered at the whim of its leader with little or no constraint, such as Iraq when it was ruled by the late Saddam Hussein or the former Soviet Union under the control of the late Joseph Stalin.

Lack of faith that the rule of law will be followed-by either a country's government or its citizens-may erode confidence, discourage corporations from conducting business, and in the situation described in this Article, deter consumers from purchasing new musical compositions. If consumers no longer purchase legal downloads of new music ${ }^{154}$ either foregoing any download or, in the alternative, downloading the song in an infringing manner-this could affect the business models of recording companies, purveyors of music scores, and retail stores. ${ }^{155}$ If

150. 56 DePaul L. ReV. 593, 593 (2007).

151. Id. at 596 (quotation marks omitted) (quoting Seymour Martin Lipset, The Social Requisites of Democracy Revisited: 1993 Presidential Address, 59 AM. Soc. Rev. 1, 15 (1994)).

152. Id. at 598.

153. Id. (quoting Martin Krygier, Marxism and the Rule of Law: Reflections After the Collapse of Communism, 15 LAW \& SOC. INQUIRY 633, 646 (1990)).

154. New compositions - and the sound recordings thereof - are most likely to be subjects of infringement suits. Older songs have passed the "test of time" and are less likely to infringing.

155. See generally Daniel J. Wakin, Free Trove of Music Scores on Web Hits Sensitive Copyright Note, N.Y. TIMES, Feb. 22, 2011 at A1 (noting the effect of open-source websites offering 
consumers choose to forgo any download, then new artists would be stifled in their ability to have their music proliferated among the masses, contrary to the purpose of the 1976 Act. ${ }^{156}$

When contemplating the Copyright Act of 1976, Congress never intended to transform everyone who buys a best-selling song into an infringer because it is later discovered that the downloaded musical composition is infringing another. ${ }^{157}$ One should seriously question whether casting an infringement net around large masses of consumers who have made purchases in good faith is the kind of behavior society wishes to encourage.

music scores on traditional publishers).

156. Fogerty v. Fantasy, Inc., 510 U.S. 517, 524 (1994) ("The primary objective of the [1976] Act is to encourage the production of original literary, artistic, and musical expression for the good of the public.").

157. See supra notes 75-76 and accompanying text. 